\title{
Comparative Foreign Policy Analysis
}

Jeffrey S. Lantis and Ryan K. Beasley

\begin{abstract}
Comparative foreign policy analysis (CFP) is a vibrant and dynamic subfield of international relations. It examines foreign policy decision-making processes related to momentous events as well as patterns in day-to-day foreign interactions of nearly 200 different states (along with thousands of international and nongovernmental organizations). Scholars explore the causes of these behaviors as well as their implications by constructing, testing, and refining theories of foreign policy decisionmaking in comparative perspective. In turn, CFP also offers valuable lessons to government leaders.

This essay surveys the evolution of CFP as a subfield over time, with special attention to its contributions to academic understanding and policy-making. It begins with a review of the characteristics and contributions of CFP, followed by acknowledgment of early works that helped establish this area of study. The next section of the essay reviews major thematic focuses of CFP, including theories of international pressures and factors that may drive state foreign policy as well as strong foundations in studies of domestic politics. Key internal actors and conditions that can influence state foreign policies include individual leaders, institutions and legislatures, bureaucratic organizations and government agencies, and public opinion and nongovernmental organizations. Following this survey of actors and contemporary theories of their role in foreign policy-decision making, the essay develops two illustrations of new directions in comparative foreign policy studies focused on political party factions and role theory in comparative perspective.
\end{abstract}

Keywords: Comparative foreign policy, decision-making, international conflict and cooperation, domestic actors, international relations theory, factionalism, role theory 


\section{Introduction}

Comparative foreign policy analysis (CFP) is a vibrant and dynamic subfield of international relations. It examines foreign policy decision-making processes related to momentous events as well as patterns in day-to-day interactions of nearly 200 different states (along with thousands of international and nongovernmental organizations). In many ways, CFP offers theoretical frameworks that help capture the 'heartbeat' of global politics. Scholars explore key questions and problems over time, including the causes of state behaviors as well as their implications by constructing, testing, and refining theories of foreign policy decisionmaking in comparative perspective (Brummer and Hudson 2015; Breuning 2007). In turn, CFP also offers valuable lessons for governance (Kaarbo 2015; Houghton 2007; Hudson 2005).

This essay proceeds as follows. First, it examines distinguishing characteristics of the development of the comparative foreign policy subfield, including its evolutionary focus and interdisciplinarity. It explores key actors engaged in foreign policy-making, from individual decision makers and small groups to states and international organizations. Second, the essay examines contemporary areas of focus in the scholarship, including questions of links to international relations theories such as neorealism and constructivism, and agent-structure explorations of how domestic and individual-level factors may impact state foreign policy behaviors. Third, it surveys methodological approaches in the subfield, with special attention to the blend of richness and rigor in many studies. Finally, this essay explores several promising avenues of current investigation - the applicability of social psychological models to explain majority-minority interactions in foreign policy-making and the potential for national role conceptions to influence state foreign policy in predictable patterns. Both examine critical questions of agency and structure and illustrate opportunities for advancement of middle-range theory in the subfield.

\section{Studying Foreign Policy in Comparative Perspective}

The development of the comparative foreign policy subfield reflects several key characteristics. First, even though CFP has deep roots, it is relatively young. The origins of this area of study date back to mid 20 ${ }^{\text {th }}$ century scholarship (Snyder et al. 1954; Sprout 1957; Rosenau 1966). Second, CFP is inherently interdisciplinary-drawing from theories and ideas in many related disciplines. Third, and perhaps surprisingly, CFP also is a rather cohesive subfield, populated by several generations of scholars who sought to advance theoretical understanding of foreign policy-making in comparative perspective. These qualities have enabled advancements in theory that represent fascinating potential contributions to broader international relations scholarship. Fourth, CFP is also a highly policy-relevant subfield, with insights about subjects, lessons of history, actors, factors, and conditions that can be incredibly useful for decision-makers. Each of these qualities of CFP is explored in further detail below.

CFP emerged as a variant of international relations and diplomacy studies in the mid- $20^{\text {th }}$ century, and quickly evolved original frameworks for policy analysis. It connects the study of international relations (the way states relate to each other in international politics) with the study of domestic politics (the functioning of governments and the relationships among individuals, groups, and institutions). Because theories of international relations are primarily concerned with state behavior, the study of international relations includes explanations of foreign policy. Traditional theories, however, tend to focus on the external environment as the primary or single explanation of why states do what they do in global affairs. Those who study foreign policy certainly draw on these theories, as will be discussed shortly, but they also look at theories of 
domestic politics focused inside the state for further explanation. Theories of domestic politics, found in the study of U.S. politics and in the study of comparative politics, share this attention to internal factors. These theories, however, tend to explain the functioning of the state or political system and the domestic policies that are chosen-they rarely comment about the effects of internal politics on a state's foreign policies.

Up to the $20^{\text {th }}$ century, scholar Deborah Gerner argues, "neither foreign policy nor international relations constituted a distinct field. Diplomatic history probably came the closest to what is now labeled as 'foreign policy,' and much of what we call international relations came under the rubric of international law, institutional analysis, or history" (1992:126). Driving much of nascent international relations theorizing at the time was realism, though it is important to note that the liberal (idealist) worldview did emerge as a way to study policy-making in the interwar years (Neack, Hey and Haney 1995). International relations assumed its contemporary form as an academic discipline after World War II. In some ways, this was in response to the rigidity of the realist framework as a search for powerful alternative theories.

Many of the founding works in the CFP subfield were interdisciplinary in nature. For example, Richard Snyder, H. W. Bruck, and Burton Sapin $(1954 ; 1963)$ drew on insights from psychology to propose a systematic decision-making framework for the study of international relations, in contrast to the virtual dismissal of human agency in realism. They championed a decision-making focus of study, analyzing behaviors of "those acting in the name of the state" (1963:65). In essence, national interest does not represent an objective universal. Rather, foreign policy choices derive from multiple sources, including the backgrounds of individual decisionmakers and the organizational framework in which decisions are made. In a similar vein, Harold and Margaret Sprout's article, "Man-Milieu Relationship Hypotheses in the Context of International Politics" (1957) called for greater attention to the "psycho milieu" of individuals and groups involved in foreign policy decisions. This focused on the international context as it is perceived and interpreted by these decision-makers. James Rosenau championed a more scientific study of foreign policy linking domestic and international conditions in his classic article, "Pre-Theories and Theories of Foreign Policy" (1966). He argued that comparative politics offered valuable insights on the "internal influences on external behavior" and that this study would bridge the fields of international and comparative politics. Critically, he called for the advancement of theory frameworks by proposing relationships between variables such as natural attributes and state behavior.

Third, the foreign policy analysis subfield is rather cohesive. Several generations of scholarship have built on early foundations to explore the causes and implications of foreign policy decisions. Subjects of study also have proliferated (read: moving from traditional diplomatic studies of great power behaviors to developing countries, and from realist-infused structural frameworks to new and alternative paradigmatic perspectives such as dependency theory). In the behavioral era of the 1960s and 1970s, many CFP scholars appeared to 'catch the fever' of Rosenau's call for generalizeable theory and the search for a scientific study of foreign policy (McGowan and Shapiro 1973). The inability of such approaches to generate substantial progress toward overarching theories of foreign policy led some to see CFP as having failed, but others argued that this ultimately resulted in a broader and more tolerant field (Smith 1986; White 1999). Indeed, subsequent generations of researchers have continued to build on and help shape the canon of CFP scholarship, and even as theory lenses have widened, comparative analysis has remained a key feature. 
Fourth, the CFP subfield is policy-relevant. Drawing on insights from decades of inquiry, foreign policy analysis has made valuable contributions to theory development and policy prescriptions (Zambernardi 2016). Early examples of applications of foreign policy frames include studies of wars over independence and decolonization (Goldstein and Keohane 1993; Kahler 2014), attempts to manage the Arab-Israeli conflict (Brecher 1984; Aoun 2003; Spiegel 1986; Hinnebusch and Ehteshami 2014; ), and studies of humanitarian intervention (Clarke and Herbst 1997; Smillie and Minear 2004). CFP scholars also played a prominent role in articulating and shaping the democratic peace thesis (Russett 1993; Ray 1995; Doyle 2011). CFP scholars have contributed a great deal to understanding transitions to democracy and the critical role that different forms of democracy can play in shaping foreign policy in the post-Cold War era (Blanton 2005; Coleman and Lawson-Remer 2013). Alexander George, one of the pioneers in the study of foreign policy, made explicit the call for scholars and practitioners to 'bridge the gap' (1993) in the hopes of improving policy and policymaking.

In the next section, we explore some of the key questions and problems that have motivated research on CFP over time. Here we also note several defining features that have come to characterize much comparative foreign policy analysis research. First, it is agent-centered, taking seriously the importance of actors that are involved in making foreign policies. Second, both the international system and domestic political contexts are viewed as important influences on foreign policy and policymakers. Third, while objective material conditions are seen as important, the subjective understandings and interpretations of individuals are also viewed as a significant factor shaping foreign policy. Fourth, while generally committed to developing theories and trying to explain foreign policy through causal inferences, the field embraces a very wide variety of specific research methods, spanning both quantitative and qualitative approaches. Finally, CFP research can be usefully organized into different 'levels of analysis' (see Singer 1961) defined by the primary factors that are used to explain foreign policy, ranging from those external to states to those internal to the minds of foreign policy decision makers. This serves as an organizational platform for the discussion that follows, drawing attention to agency, contextualism, subjectivity, and different methodologies.

\section{Contemporary Dimensions of Study in CFP}

CFP analysis begins with theories that identify different factors, actors, and conditions that can influence state foreign policies. Scholars recognize that any such explanation typically involves multiple factors, or 'variables' that drive research in CFP. Levels of analysis offers a framework for categorizing the impact of these factors. First, international system dynamics may help to explain state foreign policy development-such as how the international system is organized, the characteristics of contemporary international relations, and the actions of others. Scholars posit that these factors can cause the state to react in certain ways. The second category points to internal factors such as characteristics of the domestic political system-institutions, and groups - that can shape a state's foreign policy. A third category explores the influence of individual leaders and offers agent-focused perspectives on foreign policy-making.

\section{External Factors and Foreign Policy}

States are situated within an international system that may constrain the latitude of their behaviors. In a comparative sense, the global distribution of economic wealth and military power allows some powerful states to pursue their preferred options in foreign policy, but disadvantages others. For example, the People's Republic of China may have greater opportunity to influence 
regional politics than do the Philippines or Vietnam. Realism has been a dominant framework of explanation in international relations scholarship for nearly a century, and scholars have argued that states' foreign policies are solely a product of the international system-merely a reaction to external conditions and other actors. Realism operates on the assumption of anarchy-the absence of an overarching government in the international system-as one of the most important external conditions that affect foreign policies. In an anarchic world, states must look out for their own interests. The result, realists argue, is distrust, competition, and conflict among states (Wohlforth 2008; Lobell, Ripsman, and Taliaferro 2009). These are reflected in challenges such as the difficulty of constructing security communities in the Asia-Pacific region or negotiating an end to tensions in the Middle East (Acharya 2001).

Although various approaches to realism can capture important aspects influencing state foreign policies - the primacy of security interests and the drive for power among all statesthey do have some noted limitations. Neorealism, or 'structural' realism, for example, has been critiqued for focusing on structures and anarchy, which are relatively constant, while at the same time trying to account for variations in individual states' foreign policy behaviors (Barkin 2009; Elman 2007). Indeed, it is not entirely clear whether or not Neorealism is a theory of foreign policy at all: Offensive realists, such as Mearsheimer clearly claim to explain the power-seeking propensities of states (2001), while defensive realists like Waltz explicitly deny this represents a theory of foreign policy (Waltz 1979). Neo-Classical Realism (cf. Rose 1998) focuses on foreign policy and has continued to give primacy to power as the driver of states' behaviors while introducing various factors inside the state into their explanations.

Economic power, and not just economic wealth to purchase military capability, can give a state influence in international politics through programs such as sanctions or promises of an economically rewarding relationship. Indeed, because of changes in the international system, economic power may be more significant in an era of increasing interdependence and globalization (Wivel 2005). Liberalism focuses on the emergence of interdependence in the international system (Keohane and Nye 1997) that persuades states to find cooperation, rather than conflict, more in line with their interests (Doyle 1997). Economic liberalism argues that all states will be better off if they cooperate in a worldwide division of labor, with each state monopolizing on its comparative advantage in production.

Theories of liberalism cast a wide net for explanations of foreign policy. A centerpiece is their attention to the importance of international organizations to help coordinate cooperative efforts by states. What autonomy may be sacrificed in the short term, liberals believe, is offset by the long-term benefits of stability, efficiency, and greater wealth (Keohane 1984; Martin and Simmons 1998). International governmental organizations have especially strong potential influence in the modern system, seen in the capacities of organizations such as the United Nations and the World Trade Organization to shape different states' foreign policies. Liberalism also recognizes the growing power of non-state actors in a complex, interdependent system, and these actors increasingly influence the foreign policies of states. The rise of multinational corporations and their influence in a globalized system has changed international political dynamics. Globalization may connect more economies in worldwide financial and trading markets, but it has not done so evenly. Dynamics of regional economic integration illustrate contemporary opportunities and challenges in globalization. Both rich and poor states are engaging in agreements and dialogues to establish greater interdependence at the regional level. The European Union (EU) is the most successful effort, particularly with the establishment in 1999 of a common currency. There have been other recent attempts at regional integration in 
Africa, the Middle East, and Latin America in response, in part, to globalization. Thus, regional integration provides another layer of external factors that may affect states' foreign policies. Interestingly, however, EU states have persistently struggled to coordinate their non-economic foreign policies.

Constructivism offers valuable contributions to CFP and international relations. From a constructivist perspective, the international system is composed of the social interactions of states and shared understandings of them in international society (Kaarbo 2015). For constructivism, anarchy and interests are not defined structural constraints, rather they are constituted by the actions of agents, such as states, and the meanings, or ideas, that agents attach to them (Onuf and Klink 1989; Wendt 1999). Norms of appropriate behavior, for example, become international structures that constrain states' foreign policies (Kratochwil 1989). Whether or not states should intervene for humanitarian reasons, trade slaves, or develop nuclear weapons are all examples of norms that have changed over time. States may contribute to the development of norms, such as actions by the Austrian government to promote a humanitarian norm related to banning nuclear weapons or the role of Canada in fostering international negotiations on banning land mines. Constructivists also argue that states often avoid violating norms, even if it is in their interest to do so, and when they do violate standards for appropriate behavior, other actors may sanction them or shame them, even if they lack traditional notions of power or if condemnation is not in line with their material interests (Keck and Sikkink 1998). Although states do not always comply with international laws, the system does seem to carry some kind of moral, normative authority that states support (Lantis 2016; Hurd 2007; Ku and Diehl 1998). In these ways, ideational, and not just material conditions, do shape foreign policies.

Neo-Marxist dependency theory offers an alternative set of explanations for foreign policy in comparative perspective (Wallerstein 1974). For example, some studies of African foreign economic relations highlight the importance of their post-colonial drives for development and their relations with international organizations including the World Bank and International Monetary Fund (Callaghy 2009). These relationships sometimes complicate questions of independence, however, as developing countries see domestic and even foreign policy decisions impacted by their need for strong relations with benefactors. Other studies highlight the dependent asymmetry of many ties between developing countries and international organizations (Shaw and Okolo 1994; Nzomo and Nweke 1982), which can translate through voting patterns in the United Nations or other initiatives (Moon 1983; Holloway and Tomlinson 1995). Related studies have examined dependency and foreign policy implications in Asia (Weinstein 2006) sub-Saharan Africa (Ahiakpor 1985), and Latin America and the Caribbean (Ferris and Lincoln 1981; Mora and Hey 2004; Braveboy-Wagner 2008). And in recent work, Giacalone (2015) adapts a dependency lens to analyze Latin American foreign policies as hybrid extensions of realism (what she terms "peripheral neo-realism") and idealist approaches ("peripheral neoidealism”).

In summary, scholars have proposed a range of external factors that may impact states' foreign policies. Realism proposes that states motivated by self-interests will seek military power and create alliances, and that weak states will often submit to more powerful actors. Liberalism suggests that an interdependent international system will result in more cooperative foreign policies, support for organizations that help coordinate activities, and submission of economically weak states to the forces of the international marketplace. Constructivist perspectives point to socially-created meanings that develop into international norms which in 
turn guide actors' behaviors. Proponents of each of these perspectives agree that foreign policies are a result of states' rank, status, and links to other actors in the international system.

\section{Internal Factors and Foreign Policy}

CFP scholars have developed a substantial literature focused on internal sources of foreign policy. These works highlight the CFP focus on agents within domestic political contexts, and examine the great diversity of political systems, cultures, and leaders that may result in different foreign policy decisions by states, even in the face of similar external pressures. These often challenge the parsimony of realism or the international institutional focus of liberalism to introduce greater complexity associated with the actors, factors, and conditions that may drive state behavior more directly. These works also showcase connections to comparative politics research on domestic political systems, by showing how these factors may alter states' international behavior.

Government institutions represent a first set of domestic actors and conditions that can impact foreign policy decision-making. The prevailing scholarship in CFP focuses on democratic systems where decision-making authority is somewhat diffuse, while other work attends to authoritarian systems. The foreign policy process can be quite different for democraciesdecision-making authority tends to be diffused across democratic institutions, and thus more actors are involved. While leaders in authoritarian systems may prefer to make decisions by themselves, they too can face domestic constraints (Weeks 2012) and may have to deal with divided institutional authority (Hagan 1994). Democratic leaders, however, are directly accountable to political parties and the public and thus must often build a consensus for foreign policy.

Liberal theory argues that because of these differences in government organization, democracies will behave more peacefully than will authoritarian systems (Bausch 2015; Maoz and Russett 1993; Jakobsen et al. 2016). The difficulty of building a consensus among a larger set of actors and mobilizing them for conflict constrains the war-making abilities of democratic leaders. Furthermore, democratic institutions are built on and create a political culture that is likely to emphasize the value of peaceful resolution. However, despite these expectations, the proposition that democracies are generally more peaceful in their foreign policy is not supported by most evidence. Democracies and authoritarian governments, it seems, are both likely to be involved in and initiate conflict. Democracies, however, rarely fight other democracies (Rosenau et al. 1996). Other scholars (Calleros-Allarcon 2009; Zakaria 2003) focus on links between degrees of democracy and conflict, arguing that illiberal systems tend not to formulate foreign policies that promote global peace.

Second, bureaucratic structures and processes also affect foreign policy. State bureaucracies are charged with gathering information, developing proposals, offering advice, implementing policy, and, at times, making foreign policy decisions. Because of the complexities involved in dealing with the many issues of international politics, governments organize themselves bureaucratically, assigning responsibility for different areas or jurisdictions of policy to separate agencies or departments. Scholars have shown that this has serious implications for foreign policy (Kaarbo 1998; Allison 1974; Hollis and Smith 1986; Marsh 2014). Bureaucratic conflict is a common problem, for example, in the process of making foreign policy in the United States and Japan. The conflict in viewpoints may create inconsistent foreign policy if departments are acting on their own, rather than in coordination. It may also result in 
compromises that are not necessarily in the best interests of the state (Holsti 1972; Ball 1974). While many studies have focused on applications in a few select countries, scholars have begun to explore applicability of bureaucratic politics to other cases of foreign policy decision-making in countries such as China (Qingmin 2016), Argentina and Chile (Gertner 2016), and Sweden and Finland (t'Hart et al 1997).

Societal groups represents a third important set of actors that can impact foreign policy decision-making. Studies show that leaders may be more likely to pay attention to and react to the opinions of specific, organized societal groups than to the society at large as they play the role of linking society to the state or of opposing and competing with the state. Interest groups articulate a particular societal sector's position and mobilize that sector to pressure and persuade the government (Beyers 2008; Kirk 2008; Haney and Vanderbush 1999). These groups are varied and may be based on a single issue, on ethnic identification, on religious affiliation, or on economics countries. Economic groups often have an interest in foreign relations as they seek to promote their foreign business adventures abroad or to protect markets from competitors at home (Krasner 1978; Milner 1987). For example, China’s foreign policy engagement in Africa has been heavily influenced by economic and business interests (Sun 2014), and similar dynamics are at work in Australian commitments to India (Wesley and DeSilva-Ranasinghe 2011). Some contend ethnic interest groups are more likely to be successful when the policy in question relates to their constituency concerns and requires a congressional role in policy (Grossman and Helpman 2002; Hilsman 1971). Watanabe (1984) argues policy-makers and interest groups may establish mutually supportive relationships to help achieve policy goals. He describes these "symbiotic relationships" involving exchanges of influence and political advocacy for valuable resources such as information, votes, and campaign contributions. In this context, Congress becomes both a "target and ally" (1984:61). Ultimately, the impact of an interest group on foreign policy may depend on the particular issue, how organized the group is, resources, and the relationship between the interest group and the government (Glastris 1997; Goldberg 1990; Haney and Vanderbush 2005).

Political parties, although often part of the government, also play the role of linking societal opinion to political leadership (Hagan 1993). In many ways, political parties function much like interest groups. In some countries, such as Iran, only one party exists or dominates the political system, and the party's ideology can be important in setting the boundaries for debate over foreign policy decisions and in providing rhetoric for leader's speeches. In such cases, parties become less important than factions, which often develop within political parties. Factions are also important in political systems in which one party holds a majority in parliament and rules alone. In these countries too, factions may disagree over the direction of the country's foreign policy, as have the pro- versus anti-European integration factions in the British Conservative Party (Benedetto and Hix 2007; Rathbun 2004). Party factions may seek to outmaneuver each other or they may be forced to compromise for the sake of party unity. Even if there is a consensus within the party, foreign policy might get captured by the intraparty fighting as factions compete with one another for party leadership. In some multiparty systems, such as India, Germany, and Israel, the political scene is so fragmented that parties must enter into coalitions and share the power to make policy. In such cases, each foreign policy decision can be a struggle between coalition partners, who must get along to keep the coalition together (Ozkececi-Taner 2005; Kaarbo and Beasley 2008).

Public opinion and attitudes represent a fourth dimension of domestic factors that can impact foreign policy development. In democratic systems public opinion may, for example, be 
for or against their state intervening militarily in another country or signing a particular trade agreement. The public may agree on an issue or may be deeply divided. Scholars continue to debate the impact of public opinion on foreign policy, even in highly democratized states in which policy supposedly reflects "the will of the people". Some argue that leaders drive public opinion through framing messages in line with their preferences or that they ignore the public altogether (Entman 2004; Shapiro and Jacobs 2000; Foyle 2004; Chan and Safran 2006). But this is challenged by other works asserting that public attitudes can and do impact foreign policy decision-making at different stages (Jentleson 1992; Knecht and Weatherford 2006). Research argues that how leaders perceive and respond to public opinion can matter in select circumstances, and that public attitudes can be catalyzed by highly salient issues (Nacos et al. 2000). The media also play a role in this relationship as they too may influence public opinion on foreign policy. The information that the media provide the public may also be biased in favor of the government's policies (Entman 2004; Holsti 1992).

Finally, core values and national identities are also connected to a society's political culture-the values, norms, and traditions that are widely shared by its people and are relatively enduring over time. These enduring cultural features may also set parameters for foreign policy (Johnston 1995; Katzenstein 1996; Berger 1998). A country's culture may value, for example, individualism, collectivism, pragmatism, or moralism, and these culturally based values may affect foreign policy. Cultures that place a premium on morality over practicality, for example, may be more likely to pass moral judgment over the internal affairs and foreign policy behaviors of others. Culture may also affect the way foreign policy is made. Cultures in which consensual decision making is the norm, for example, may take longer to make policy, because the process of consultation with many people may be just as important as the final decision (Hudson 1997; Sampson 1987). However, despite the general recognition that cultural particularities do affect foreign policy, such concepts can be difficult to operationalize and measure (whether quantitatively or qualitatively), and this has limited some assessments of culture and foreign policy (Lantis 2015; Hudson 1997).

\section{Individual Leaders and Foreign Policy}

Leaders sit 'at the top' of government. In many political systems, the head of state or head of government has substantial authority to allocate state resources and make foreign policy. CFP provides fertile ground for the development of substantial comparative work on leadership in foreign policy, in part because the potential influence of key individuals in power represents an important commonality across different political systems and regions (Kamrava 2011; Korany et al. 1991). For example, fascinating studies have been developed on the role of leadership in the foreign policy of Arab states (Hinnenbusch 2015), President Dilma Rousseff's influence on Brazilian foreign policy over the past decade (De Jesus 2014), and the impact of individual leaders on nuclear weapons programs in France, Australia, Argentina, and India (Hymans 2006).

Studies show that individual characteristics of leaders matter in influencing foreign policy decisions (Hermann 1980; Levy 2003). Characteristics of leaders seem to be more important when the situation is ambiguous, uncertain, and complex, and when the leader is involved in the actual decision-making rather than delegating his or her authority to advisers (Gallagher and Allen 2014; Greenstein 1975). Under such conditions a leader's personality and beliefs may be especially influential in foreign policy, but determining whether or not leaders have influenced foreign policy can be challenging (Jervis 2013).

CFP analysts also have explored the roots of individual leaders' decisions in their 
personal history. Childhood or early political experiences, for example, may have taught policymakers how certain values and ways of handling problems are important (George and George 1956). Leaders' cognitions and belief systems also influence foreign policy (Rosati 2000). Human beings tend to prefer consistency in ordering the world around them, and thus often ignore or distort information that contradicts what they already believe (Beasley 2016). Studies show this is especially likely when we have strongly held "images" of other countries. Leaders who see another country as their enemy, for example, will often selectively attend to or perceive information about that country in a way that confirms their original belief. For this reason, images are extremely resistant to change, even if the "enemy" is making cooperative gestures (Holsti 1976; Jervis 1976; Vertzberger 1990).

Political psychologists have made important contributions to understanding foreign policy decision-making. Here, scholars argue that leaders can be categorized into types of personalities. Some leaders, for example, may be motivated by a need to dominate others and may thus be more conflictual in foreign policy, whereas others may be more concerned with being accepted, and may therefore be more cooperative. Some leaders are more nationalistic, more distrustful, and believe that the world is a place of conflict that can only be solved through the use of force, whereas others see themselves and their state as part of the world community that can be trusted and believe that problems are best solved multilaterally (Dyson 2006; Schafer and Walker 2006; Hermann 1980). Leaders' decision-making style or how they manage information and the people around them can also be important. Some leaders may choose to be quite active in foreign policy-making, whereas others champion isolationism. Some leaders are "crusaders" who come to office committed to a foreign policy goal; others are interested in keeping power or bridging conflicts. They tend to be sensitive to advice and are reluctant to make decisions without consultation and consensus (Goemans and Chiozza 2011; Hermann 1993; Kaarbo 1997).

\section{Methodologies}

Given the breadth of issues that concern those who study foreign policy, it is perhaps not surprising that CFP researchers employ a wide variety of methods in their efforts to investigate factors influencing the behavior of states. This pluralism, however, is tempered by a somewhat more narrow epistemological commitment by most CFP work to developing generalizable explanations of foreign policy. In this sense, much CFP work stands in contrast to epistemological approaches emphasizing subjective 'understanding' (Hollis and Smith 1986) or any of a variety of other approaches that eschew explanation and generalizability as research goals (Tickner 1997; White 1999; Houghton 2007). But consistent with its early focus on the interpretations of decision makers, a number of approaches take seriously the subjective experiences of individuals as they seek to understand the world.

CFP has deep roots in comparative politics, and draws from the methods employed in that sub-field. Lijphart's (1971) seminal work closely examined the comparative method and the logic of comparative analysis with a small number of cases ('small-n' studies), contrasting it with experiments, statistical analysis, and single case studies (Collier 1993). Subsequently, small-n analysis has been refined and more sophisticated approaches to case selection and comparative case study design have emerged (Kaarbo and Beasley 1999). In particular, 'process tracing' has been put forward as an important contribution to case study methods (Beach and Pedersen 2013; George and Bennett 2005) as a technique for exploring the underlying causal mechanisms involved (Falleti and Lynch 2009). The case study method is particularly attractive 
to CFP researchers who are interested in specific decisions, or who may be motivated to improve actual policymaking processes.

In contrast to comparative case study approaches, many CFP scholars have employed broad statistical comparisons using established datasets, such as the Correlates of War (Singer) data set and the Militarized Interstate Disputes (Ghosn, Palmer and Bremer, 2004) data set. The development of large events-based datasets for the study of foreign policy-such as the Conflict and Peace Data Bank (COPDAB; Azar 1980, 1982) and the Comparative Research on the Events of Nations (CREON; Hermann et al. 1973) data set-were driven by the desire to bridge traditional and more quantitative approaches (Schrodt 1995). Indeed, events data offer a more nuanced and wide ranging set of dependent variables than the more conflict-oriented datasets that focus more on conflict and war (Oktay \& Beasley 2016). Moving toward more event-based datasets, McClelland (1978), for example, created the 'World Event Interaction Survey, or 'WEIS', data set which coded the discreet behaviors of countries around the world. Scholars such as Goldstein (1992) translated these categories into levels of conflict or cooperation, offering opportunities for more nuanced examinations beyond war and militarized disputes. This trend has continued, offering new sources for the statistical study of foreign policy (Gerner and Schrodt 1994; King and Lowe, 2004; Merritt 1994).

Scholars of CFP who seek explanations that lie with individuals and small groups of decision makers can have difficulty accessing relevant data, often relying on archival analysis of decision-making and detailed historical case studies. Content analysis and 'at-a-distance' techniques, however, have offered ways to study decision makers and infer individual-level characteristics. These studies rely primarily on analyzing speeches and writings, often using computer software, and large datasets have been constructed that include measures of world leaders' beliefs and personality traits (Young and Schafer 1998). Such data collection techniques are not without problems, but they have allowed scholars to link individual-level characteristics with foreign policy decisions, giving greater access to subjective qualities of actors and their impact on foreign policy outcomes. Finally, concern with the micro-processes of individual and group decision-making has led scholars to employ laboratory experiments as a way of testing specific psychological dynamics in a controlled environment (Geva, Mayhar, \& Skorick 2000; McDermott 2011).

\section{Foreign Policy Theories in Action}

This section briefly explores pathways that link theory and practice in foreign policy development. This work underlines the important contributions of the subfield to date and offers examples of avenues for future advancement of the subfield.

\section{Social Psychology and Minority Influence in Foreign Policy}

Among the many fertile areas for further research on foreign policy in comparative perspective is the study of the relationship between factionalism and foreign policy. Factions can be defined as "any intra-party combination, clique, or grouping whose members share common identity or purpose, and are organized to act collectively_as a distinct bloc within a party - to achieve their goals” (Zariski 1960:33). In studies of factionalism in Britain, Canada, Italy, and Japan, Francoise Boucek observes, "Political parties are not monolithic structures but collective entities in which competition, divided opinions and dissent create internal pressure" (2009:455; 2012). Additional studies in comparative politics examine typologies of intra-party groups with different attributes, including organization, function and role, and they discuss projected impacts 
on political outcomes (Boucek 2009: 456; Belloni and Beller 1978). Other work identifies links between factionalism, party government, and Cabinet durability in parliamentary regimes (Köllner and Basedau 2005).

Emerging studies recognizing factions as agents of change open exciting new avenues for foreign policy analysis in comparative perspective (Koger, Masket, and Noel 2010; Barret and Eshbaugh-Soha 2007). For example, Jeffrey Peake (2002) studies links between intraparty factionalism and U.S. foreign policy outcomes. He explores conditions that contribute to foreign policy challenges, as well as factors that might lead to greater opportunity for presidential coalition-building and advancement of their foreign policy agendas (Peake 2002; Peake, Krutz, and Hughes 2012). Gvosdev and Marsh (2013) also examine how different interests and factions have influenced Russian foreign policy in the Putin-Medvedev eras.

Contemporary research in social psychology also offers promising insights on how intraparty factionalism, or majority-minority differences, may influence the political process. For much of the $20^{\text {th }}$ century, the traditional 'conformity thesis' held that dissident voices in groups tend to yield to the majority position even when it is incorrect (Allen 1965; Sherif 1935; Maass and Clark 1984; Milgram 1963; 1965). However, Moscovici and others (Moscovici, Lage and Naffrechoux 1969; Moscovici and Faucheaux 1972) successfully challenge traditional assumptions by showing how group members may exhibit deviance or nonconformity by attempting to persuade others to endorse alternative decisions. Minority views must be consistent in presentation and support for policy change. Over time, numerous studies (Maass and Clark 1984; Moscovici et al. 1985) have reinforced the central premise of minority influence theory: consistent behavior by minorities will exert influence, whereas inconsistent behavior is likely to fail to bring about any change of the majority's attitudes and perceptions (Tanford and Penrod 1984; Moscovici and Personaz 1980). Related studies find minority influence to be most effective if alternative voices have enough time to present their position (Wachtler 1977), argue in a firm but flexible manner (Mugny 1975), and share the same social category as the majority (Maass, Clark and Haberkorn 1982). Hagan et al. (2001) also have argued that the interactions between minority and majority positions, or between government and opposition, can produce alternative outcomes including deadlock, compromise, and more serious policy inconsistencies. Kaarbo (2008:57) asserts, “The psychological processes involved in group polarization, persuasion, and other influence strategies” play critical roles in shaping outcomes.

Social psychological studies of factionalism offer potential for further comparative analysis of foreign policies. These themes are ripe for application to the study of phenomena such as centrifugal forces in the European Union (with the 2016 'Brexit' referendum and dynamic tensions over issues such as debt relief and Syria policy), efforts to consolidate democracy in post-war Iraq, or how the factionalism in major political parties in the United States during the 2016 presidential election threatens major foreign policy changes. This frame provides a conceptual bridge between individual and domestic levels of analysis and offers a rich avenue for future research on foreign policy in comparative perspective.

\section{Role Theory and Foreign Policy}

Role theory has burgeoned recently as an approach to comparative foreign policy analysis. In contrast to the work on party factionalism, role theory focuses more centrally on the interplay between the international system and they way in which states situate themselves within that system through their foreign policies. Role theory originates from a sociological perspective that views roles as social positions within groups, which provide cues for behavior. 
Roles themselves are socially constructed through the interactions of individuals within a given social system, and they provide more or less clear guidelines that direct behaviors and set expectations. CFP scholars adapt role theory to the international system by viewing it as a society of states, each of whom can take on specific roles. In this way role theorists manage to bridge material and ideational factors, domestic and international dimensions, and agents and structures (e.g., Barnett 1993; Harnisch 2011; Breuning 2011).

Holsti (1970) is credited with bringing role theory to the study of foreign policy. His work was situated in the Cold War period, and he drew attention to the ways in which classes of states were conceived of within the international system according to the roles that they played, such as 'regional leader' or 'faithful ally'. He explicitly connected the domestic context to the national role conception of any given state, but recognized the importance of other actors and international institutions as shaping role conceptions as well. Subsequently, role theorists have unpacked various dimensions associated with roles within the international system, and sought to understand the processes through which roles are developed, enacted, resisted, contested, and changed (cf. Cantir and Kaarbo 2016; Harnisch 2012; McCourt 2012; Walker 1987).

While there are many concepts associated with role theory generally, some have been more frequently applied by foreign policy scholars (Thies 2010). For example, scholars often label actors pursuing a role as 'Ego', and others within the international system who respond as 'Alter(s)'. Roles are social categories involving a role conception by Ego about what the role it is pursuing involves, as well as role expectations by Alter(s) about appropriate and inappropriate role behaviors. Role enactment is the foreign policy behavior of Ego, and attempts to change Ego's role involve alter-casting Ego into a different role by providing cues or sanctions. This interplay between Ego and Alter(s) is the process of role socialization, which usually involves a dominant or primary socializer. A state needs to have both the material resources and social status to effectively assume a role within the international system, that is, its master status must be consistent with the role it is taking (Thies 2013).

Role theory illustrates several key dimensions associated with CFP research. Role theory research is interested in the interaction of both domestic and international factors, as states and their leaders seek to enact roles consistent with their domestic context and expectations, while international actors may sanction role inappropriate behavior and alter-cast states into different roles. Role theory also embraces subjectivism, as roles must be understood and socially constructed through interactive processes between social agents who are interpreting cues, demands and expectations. Role theory is also sensitive to contexts, as different international systems allow for different roles, and states seek to enact particular roles in the face of situational demands and the specific cues and expectations of key alters. Roles have also been studied at different levels of analysis, ranging from the beliefs of leaders (cf. Holsti 1970) to national culture (cf. Harnish 2001), to multi-level analyses (Walker 1979), and this variety has been noted as both a strength of (Breuning 1995; Thies 2010) and challenge for (Kowert and Legro 1996) role theory.

A number of contemporary role theory studies have examined European actors, such as the Czech Republic, Germany, and the EU (Beneš and Harnisch 2015), Denmark and the Netherlands (Kaarbo and Cantir 2013), and European foreign Policy more generally (Aggestam 2006). Other applications have examined role theory in non-European regional contexts such as the Middle East (Barnett 1993; Ovah 2013), former Soviet republics (Chafetz, Abramson, and Grillot 1996), and Latin America (Wehner 2014). Individual country studies such as Indian foreign policy (Hansel and Möller 2015), British foreign policy (McCourt 2011), Chinese foreign 
policy (Harnisch et al 2016) and Moldovan foreign policy (Cantir and Kennedy 2015) have also illustrated the value of role theory in helping to account for state behavior.

Role theory offers several avenues for future research. A key issue involves the degree to which both material and ideational factors can be integrated within role theory accounts of states' behaviors. This could potentially bridge foreign policy approaches with broader international relations theories. Some recent work (Beasley \& Kaarbo 2017) has sought to explore the nature of sovereignty within the international system as it conditions the types of roles available to states and the way states socialize one another into or out of particular roles. The relationship between sovereignty and roles, however, is not entirely clear and would benefit from examinations that consider regional differences in sovereignty. Regional transformations of sovereignty associated with the UK exit from the European Union, for example, would undoubtedly benefit from an examination of the changing roles of key actors. Similarly, recent work on China's role in the international system (Harnisch et al 2016) could be extended to consider the different ways in which sovereignty and roles are transformed with the changing security dynamics in the East Asian region. Such efforts might serve to better connect the comparative foreign policy approach to role theory with broader theories of international relations.

\section{Conclusion}

This essay has explored a number of key questions and themes that have motivated CFP research over time. It has examined some of the major theoretical frameworks and variables that have driven research, as well as offered samples of the types of work that link factors to foreign policy outcomes in comparative perspective. The essay also illustrates characteristics of the development of the comparative foreign policy subfield over time, including its relative 'youth', interdisciplinarity, and scholarly commitment to cohesion. Most CFP scholarship devotes attention to agency within the broader international system and domestic political contexts, and it embraces a wide variety of specific research methods, spanning both quantitative and qualitative approaches. The subfield also draws in critical observations from related disciplines regarding subjective understandings of the foreign policy context. Along with a commitment to cohesion and cumulation of knowledge (especially of middle-range theory), these qualities have enabled advancements in scholarship in a relatively short period of time. Finally, our essay outlines important avenues for future progress in comparative foreign policy analysis. The subfield is well positioned to continue to support rich and diverse studies-with great relevance for understanding and making policy in the $21^{\text {st }}$ century.

\section{Further Reading}

Alden, Chris, and Amnon Aran. (2016) Foreign Policy Analysis: New Approaches. Second Edition. Routledge. 
Hinnebusch, Raymond A., and Anoushiravan Ehteshami. (2014) The Foreign Policies of Middle East States. Second Edition. Boulder, CO: Lynne Rienner Publishers.

Khadiagala, Gilbert M., and Terrence Lyons, eds. (2001) African Foreign Policies: Power and Process. Lynne Rienner Publishers, 2001.

Pant, Harsh V. (2016) Indian Foreign Policy: An Overview. Manchester: Manchester University Press.

Smith, Steve, Amelia Hadfield, and Tim Dunne. (2012) Foreign Policy: Theories, Actors, Cases. Oxford: Oxford University Press.

Walker, Stephen G., Akan Malici, and Mark Schafer, eds. (2011). Rethinking Foreign Policy Analysis: States, Leaders, and the Microfoundations of Behavioral International Relations. London: Routledge.

\section{References}

Acharya, Amitav. (2001) Constructing a Security Community in Southeast Asia: ASEAN and the Problem of Regional Order. London: Routledge.

Aggestam, L. (2006) Role Theory and European Foreign Policy: A Framework for Analysis. In O. Elgstrom and M. Smith (eds) The European Union's Roles in International Politics: Concepts and Analysis. London: Routledge, 11-29.

Ahiakpor, J. W. (1985) The Success and Failure of Dependency Theory: The Experience of Ghana. International Organization, 39(3), 535.

Allen, V.L. (1965) Situational Factors in Conformity. In L. Berkowitz, ed. Advances in Experimental Social Psychology. vol.2. New York: Academic Press.

Allison, G. T. (1974) Questions about the Arms Race: Who's Racing Whom?: a Bureaucratic Perspective. Public Policy Program, John F. Kennedy School of Government, Harvard University.

Ames, Barry. (1995) Electoral Rules, Constituency Pressures, and Pork-Barrel: Bases of Voting in the Brazilian Congress. The Journal of Politics 57(2): 324-343.

Aoun, E. (2003) The European Foreign Policy and the Arab-Israeli Dispute: Much Ado about Nothing? European Foreign Affairs Review 8: 289-312.

Arnold, R. Douglas. (1992) The Logic of Congressional Action. New Haven, CT: Yale University Press. 
Asch, Solomon E. (1951) Effects of Group Pressure Upon the Modification and Distortion of Judgment. In Harold Guetzkow, ed., Groups, Leadership, and Men. Pittsburgh, PA: Carnegie Press.

Asch, Solomon E. (1955) Opinions and Social Pressure. Readings about the Social Animal 193: 17-26.

Asch, Solomon E. (1956) Studies of Independence and Conformity: A Minority of One against a Unanimous Majority. Psychological monographs: General and applied 70(9).

Ball, D. J. (1974) The Blind Men and the Elephant: A Critique of Bureaucratic Politics Theory. Australian Journal of International Affairs 28(1): 71-92.

Bausch, A. W. (2015) Democracy, War Effort, and the Systematic Democratic Peace. Journal of Peace Research 52(4): 435-447.

Beasley, Ryan. (1998) Collective Interpretations: How Problem Representations Aggregate in Foreign Policy Groups. In Problem Representation in Foreign Policy Decision Making, edited by Donald Sylvan and James Voss. Cambridge: Cambridge University Press.

Beasley, R. K., Kaarbo, J., Lantis, J. S., \& Snarr, M. T. Eds. (2012) Foreign Policy in Comparative Perspective: Domestic and International Influences on State Behavior. Washington, DC: SAGE/CQ Press.

Beasley, Ryan. (2016) Dissonance and Decision Making Mistakes in the Age of Risk. Journal of European Public Policy.

Beasley, Ryan and Kaarbo, J (2017) Casting for a sovereign role: Socialising an aspirant state in the Scottish independence referendum. European Journal of International Relations. (online: http://journals.sagepub.com/doi/full/10.1177/1354066116683442)

Barkin, S. (2009). Realism, Prediction, and Foreign Policy. Foreign Policy Analysis 5(3): 233246.

Barnett, Michael. (1993) Institutions, Roles, and Disorder: The Case of the Arab States System. International Studies Quarterly 37(3): 271-296.

Barrett, Andrew W., and Matthew Eshbaugh-Soha. (2007) Presidential Success on the Substance of Legislation. Political Research Quarterly 60(1): 100-112.

Bauer, Raymond A., Ithiel de Sola Pool, and Anthony D. Lewis. (1972) American Business and Public Policy: The Politics of Foreign Trade. Chicago, IL: Aldine, Atherton.

Beach, Derek \& Pedersen, Rasmus Brun. (2013) Process-Tracing Method: Foundations and Guidelines. Ann Arbor, MI: University of Michigan Press. 
Belloni, Frank P., and Dennis C. Beller, Eds. (1978) Faction Politics: Political Parties and Factionalism in Comparative Perspective. Santa Barbara, CA: ABC-Clio.

Beneš, Vit and Sebastian Harnisch. (2015) Role Theory in Symbolic Interactionism: Czech Republic, Germany, and the EU. Cooperation and Conflict 50(1): 146-165.

Bennett, A., \& Elman, C. (2007) Qualitative Methods The View From the Subfields. Comparative Political Studies 40(2): 111-121.

Berger, T. (1998) Cultures of Antimilitarism: National Security in Germany and Japan. Baltimore: Johns Hopkins University Press.

Besley, T., Persson, T., \& Sturm, D. M. (2010) Political Competition, Policy, and Growth: Theory and Evidence from the U.S. The Review of Economic Studies 77(4): 1329-1352.

Beyers, Jan, Rainer Eising and William Maloney. (2008) Researching Interest Group Politics in Europe and Elsewhere: Much We Study, Little We Know? West European Politics 31(6): 1103-1128.

Blanton, S. L. (2005). Foreign Policy in Transition? Human Rights, Democracy, and US Arms Exports. International Studies Quarterly 49(4): 647-667.

Bond, Jon R., and Richard Fleisher, eds. 2000. Polarized Politics: Congress and the President in the Partisan Era. Washington, DC: CQ Press College.

Boucek, Françoise. (2009) Rethinking Factionalism Typologies, Intra-Party Dynamics and Three Faces of Factionalism. Party Politics 15(4): 455-485.

Boucek, Francoise. (2012) Factional Politics: How Dominant Parties Implode or Stabilize. London: Palgrave Macmillan.

Bowler, Shaun, David M. Farrell, and Richard S. Katz. (1999) Party Discipline and Parliamentary Government. Columbus, OH: The Ohio State University Press.

Braveboy-Wagner, J. A. (2008). Small States in Global Affairs: The Foreign Policies of the Caribbean Community (CARICOM). New York: Macmillan.

Brecher, M. (1972) The Foreign Policy System of Israel: Setting, Images, Process. London: Oxford University Press.

Breuning M. (2011) Role Theory Research in International Relations: State of the Art and Blind Spots. In: Harnisch S, Frank C and Maull HW. Eds. Role Theory in International Relations: Approaches and Analyses. New York: Routledge. 16-35.

Breuning, Marijke. (2007) Foreign Policy Analysis: A Comparative Introduction. London: Springer. 
Brummer, Klaus, and Valerie M. Hudson. (2015) Foreign Policy Analysis: Beyond North America. Boulder, CO: Lynne Rienner.

Cain, Bruce, John Ferejohn, and Morris Fiorina. (1987) The Personal Vote: Constituency Service and Electoral Independence. Cambridge, MA: Harvard University Press.

Callaghy, T. M. (2009). Anatomy of a 2005 Debt Deal: Nigeria and the Paris Club. Penn School of Arts and Sciences Working Paper. January 16.

https://www.sas.upenn.edu/polisci/sites/www.sas.upenn.edu.polisci/files/TC_Nigeria_long.pdf.

Calleros-Alarcó, Juan Carlos. (2009) The Unifinished Transition to Democracy in Latin America. London: Routledge.

Calvert, Randall, and Richard Fenno. (1994) Strategy and Sophisticated Voting in the Senate. Journal of Politics 56(2): 349-376.

Cantir, C., and R. Kennedy. (2015) Balancing on the Shoulders of Giants: Moldova's Foreign Policy toward Russia and the European Union. Foreign Policy Analysis, 11(4), 397.

Cantir, C., and Juliet Kaarbo. (2016). Domestic Role Contestation, Foreign Policy, and International Relations. New York, NY: Routledge.

Cantir, C., and Juliet Kaarbo. (nd) Contested Roles and Domestic Politics: Reflections on Role Theory in Foreign Policy Analysis and IR Theory. Foreign Policy Analysis, 8(1): 5-24

Carey, John M., and Matthew Soberg Shugart. (1995) Incentives to Cultivate a Personal Vote: A Rank Ordering of Electoral Formulas. Electoral Studies 14(4): 417-439.

Carey, J.M. (2009) Competing Principles, Political Institutions, and Party Unity in Legislative Voting. American Journal of Political Science 51(3).

Carey, J.M. (2009) Legislative Voting and Accountability. Cambridge: Cambridge University Press.

Chafetz, G., Abramson, H., \& Grillot, S. (1996). Role Theory and Foreign Policy: Belarussian and Ukrainian Compliance with the Nuclear Nonproliferation Regime. Political Psychology 17(4): 727-757.

Chan, S., \& Safran, W. (2006). Public Opinion as a Constraint Against War: Democracies’ Responses to Operation Iraqi Freedom. Foreign Policy Analysis 2(2): 137-156.

Chelotti, N. (2015). A ‘Diplomatic Republic of Europe’? Explaining Role Conceptions in EU Foreign Policy. Cooperation \& Conflict 50(2). 
Cialdini, Robert B. (2001) Harnessing the Science of Persuasion. Harvard Business Review 79(9): 72-81.

Clark, Russell D., III. (1994) A Few Parallels Between Group Polarization and Minority Influence. In Minority Influence, edited by Serge Moscovici. Chicago, IL: Nelson-Hall.

Clarke, W. S., and Jeffrey Herbst. eds. (1997). Learning from Somalia: The Lessons of Armed Humanitarian Intervention. Oxford: Westview Press.

Coleman, I., and T. Lawson-Remer. (2013) Pathways to Freedom: Political and Economic Lessons from Democratic Transitions.

Coman, Emanuel Emil. (2012) Legislative Behavior in Romania: The Effect of the 2008 Romanian Electoral Reform. Legislative Studies Quarterly 37(2): 199-224.

Corwin, Edward S. (1957) The President: Office and Powers, 1787-1957. New York: New York University Press.

Cox, Gary W., and Mathew D. McCubbins. (2005) Setting the Agenda: Responsible Party Government in the US House of Representatives. Cambridge: Cambridge University Press.

Crabb, Cecil Van Meter, and Pat M. Holt. (1992) Invitation to Struggle: Congress, the President, and Foreign Policy. Washington, DC: CQ Press.

De Jesus, Diego Santos Vieira. (2014) The Benign Multipolarity: Brazilian Foreign Policy Under Dilma Rousseff. Journal of International Relations and Foreign Policy 2(1): 19-42.

Depauw, S., and S. Martin. (2008) Legislative Party Discipline and Cohesion in Comparative Perspective. in D. Giannetti and K. Benoit. eds. Intra-Party Politics and Coalition Governments. Abingdon: Routledge.

DiSalvo, Daniel. (2012) Engines of Change: Party Factions in American Politics, 1868-2010. Oxford: Oxford University Press.

DiSalvo, Daniel. (2010) The Politics of a Party Faction: The Liberal-Labor Alliance in the Democratic Party, 1948-1972. The Journal of Policy History 22(3): 269-299.

DiSalvo, Daniel. (2009) Party Factions in Congress. Congress \& the Presidency: A Journal of Capital Studies 36(1).

Dodd Lawrence, C., and Scot Schraufnagel. (2013) Party Polarization and Policy Productivity in Congress: From Harding to Obama. Dodd Lawrence C, Oppenheimer Bruce I. eds. Congress Reconsidered. 10th ed. Washington, DC: Sage/Congressional Quarterly Press.

Doyle, M.W. (1997) Ways of War and Peace. Princeton, NJ: Princeton University Press. 
Doyle, M. W. (2011). International Ethics and the Responsibility to Protect. International Studies Review 13(1): 72-84.

Duverger, Maurice. (1954) Political Parties: Their Organization and Activities in the Modern State. New York: Oxford University Press.

Dyson, S.B. (2006) Personality and Foreign Policy: Tony Blair's Iraq Decisions. Foreign Policy Analysis 2(3): 289-306.

Ehteshami, A., and R. Hinnebusch. (2014). Syria and Iran. New York: Routledge.

Elman, Colin. (1996) Horses for Courses: Why Not Neorealist Theories of Foreign Policy? Security Studies 6(1): 7-53.

Enelow, James, and David Koehler. (1981) The Amendment in Legislative Strategy:

Sophisticated Voting in the US Congress. Journal of Politics 42(2): 1062-1089.

Entman, R. M. (2004). Projections of Power: Framing News, Public Opinion, and US Foreign Policy. Chicago, IL: University of Chicago Press.

Falleti, T. G., \& Lynch, J. F. (2009). Context and Causal Mechanisms in Political Analysis. Comparative Political Studies 42(9): 1143-1166.

Farquharson, Robin. (1969) Theory of Voting. New Haven, CT: Yale University Press.

Ferris, E. G., \& Lincoln, J. K. (Eds.). (1981). Latin American Foreign Policies: Global and Regional Dimensions. Boulder, CO: Westview Press.

Fordham, Benjamin O. (2009) The Limits of Neoclassical Realism: Additive and Interactive Approaches to Explaining Foreign Policy Preferences. In Lobell, Ripsman, and Taliaferro. Eds. Neoclassical Realism, The State, and Foreign Policy. Cambridge: Cambridge University Press.

Foyle, D.C. (2004) Leading the Public to War? The Influence of American Public Opinion on the Bush Administration's Decision to Go to War in Iraq. International Journal of Public Opinion Research 16(4): 269-294.

Fukui, Haruhiro. (1978) Japan: Factionalism in a Dominant-Party System. In Faction Politics: Political Parties and Factionalism in Comparative Perspective. Beller and Belloni. eds. Santa Barbara, CA: ABC-CLIO, Inc.

Gallagher, Maryann, and Susan Allen. (2014) Presidential Personality: Not Just a Nuisance. Foreign Policy Analysis 10(1): 1-21.

Goemans, Hein, and Giacomo Chiozza. (2011) Leaders and International Conflict. Cambridge: Cambridge University Press. 
Garrison, Jean. (2007) Constructing the 'National Interest in US-China Policy Making: How Foreign Policy Decision Groups Define and Signal Policy Choices. Foreign Policy Analysis 3:105-126.

George, A. L., and S. W. Lewis (1993). Bridging the Gap: Theory and Practice in Foreign Policy. Washington, DC: United States Institute of Peace Press.

George, A. L., \& Bennett, A. (2005). Case Studies and Theory Development in the Social Sciences. Cambridge, MA: MIT Press.

Gerner, D.J. (1992) Foreign Policy Analysis: Exhilarating Eclecticism, Intriguing Enigmas. International Studies Notes 18(4).

Gerner, D. J., and P.A. Schrodt. (1994). Machine Coding of Events Data Using Regional and International Sources. International Studies Quarterly 38(1).

Gertner, Andres V. (2016). Autonomy and Negotiation in Foreign Policy: The Beagle Channel Crisis. London: Palgrave-Macmillan.

Geva, N., Mayhar, J., \& Skorick, J. M. (2000). The Cognitive Calculus of Foreign Policy Decision Making An Experimental Assessment. Journal of Conflict Resolution 44(4): 447-471.

Ghosn, F., Palmer, G., and Bremer, S.A. (2004) The MIDS Data Set, 1993-2001: Procedures, Coding Rules, and Description. Conflict Management and Peace Science 21(2): 133-154.

Giannetti, D. and K. Benoit eds. (2008) Intra-Party Politics and Coalition Governments. Abingdon: Routledge.

Goldstein, J.S. (1992) A Conflict-Cooperation Scale for WEIS Events Data. Journal of Conflict Resolution 36(2): 369-385.

Goldstein, J., and Keohane, R.O. eds. (1993) Ideas and Foreign Policy: An Analytical Framework. In J. Goldstein, and R.O. Keohane (eds.) Ideas and Foreign Policy: Beliefs, Institutions, and Political Change. Ithaca, NY: Cornell University Press.

Greenstein, F. I. (1975). Personality and Politics: Problems of Evidence, Inference, and Conceptualization. New York: Norton.

Gvosdev, Nikolas K., and Christopher Marsh. (2013) Russian Foreign Policy: Interests, Vectors, and Sectors. CQ Press, 2013.

Hagan, Joe D. (1993) Political Opposition and Foreign Policy in Comparative Perspective. Boulder, CO: Lynne Rienner.

Hagan, J. D. (1994). Domestic Political Systems and War Proneness. Mershon International Studies Review, 38 (Supplement 2): 183-207. 
Hagan, Joe D., Philip P. Everts, Haruhiro Fukui, and John D. Stempel. (2001) Foreign Policy by Coalition: Deadlock, Compromise, and Anarchy. International Studies Review 3(1):169-216.

Haney, P. J., and W. Vanderbush. (1999). The Role of Ethnic Groups in US foreign policy: The Case of the Cuban American National Foundation. International Studies Quarterly 43(2): 341361.

Hansel, M., and M. Moeller (2015). Indian Foreign Policy and International Humanitarian Norms: A Role-Theoretical Analysis. Asian Politics \& Policy 7(1).

Harnisch, S. (2011) Role Theory: Operationalization of Key Concepts. In: Harnisch, S., C. Frank, and H.W. Maull. Eds. Role Theory in International Relations: Approaches and Analyses, London: Routledge.

Harnisch, S. (2012). Conceptualizing in the Minefield: Role Theory and Foreign Policy Learning. Foreign Policy Analysis, 8(1): 47-69.

Harnisch S, Bersick S, Gottwald J-C (eds) (2016) China’s International Roles. London: Routledge.

Heidar, Knut, and Ruud Koole. (2000) Parliamentary Party Groups Compared. Parliamentary Party Groups in European Democracies. Political Parties behind Closed Doors.

Hermann, C.F. (1978) Decision Structure and Process Influences on Foreign Policy. In M.A. East, S.A. Salmore, and C.F. Hermann. Eds. Why Nations Act. Beverly Hills, CA: Sage.

Hermann, C.F., and Peacock, G. (1987) The Evolution and Future of Theoretical Research in the Comparative Study of Foreign Policy. In C.F. Hermann, C.W. Kegley, and J.N. Rosenau (eds.) New Directions in the Study of Foreign Policy. Boston, MA: Allen \& Unwin.

Hermann, C.F., Kegley, C.W. Jr., and Rosenau, J.N. eds. (1987) New Directions in the Study of Foreign Policy. Boston, MA: Allen \& Unwin.

Hermann, Margaret G. (1980) Explaining Foreign Policy Behavior Using the Personal Characteristics of Political Leaders. International Studies Quarterly 24.1 (1980): 7-46.

Hermann, M.G., Preston, T., Korany, B., and Shaw, T.M. (2001) Who Leads Matters. International Studies Review 3(2): 83-131.

Hinckley, B. (1994) Less Than Meets the Eye: Congress, the President, and Foreign Policy. Chicago, IL: University of Chicago Press.

Hine, David. (1982) Factionalism in West European Parties: A Framework for Analysis. West European Politics 5(2): 36-53. 
Hinnebusch, Raymond A., and Anoushiravan Ehteshami. (2014) The Foreign Policies of Middle East States. Second Edition. Boulder, CO: Lynne Rienner Publishers.

Hollis, M., \& Smith, S. (1986). Roles and Reasons in Foreign Policy Decision Making. British Journal of Political Science 16(3): 269-286.

Holloway, S. K., \& Tomlinson, R. (1995). The New World Order and the General Assembly: Bloc Realignment at the UN in the Post-Cold War World. Canadian Journal of Political Science 28(2): 227-254.

Holsti, K. (1970) National Role Conceptions in the Study of Foreign Policy. International Studies Quarterly 14: 233-309.

Holsti, K. J., and O.R. Holsti (1972). International Politics: A Framework for Analysis (No. 327). New York: Prentice-Hall.

Holsti, O.R. (1976). Foreign Policy Formation Viewed Cognitively. Structure of Decision. 1854. Princeton, NJ: Princeton University Press.

Holsti, O. R. (1992). Public Opinion and Foreign Policy: Challenges to the Almond-Lippmann Consensus. International Studies Quarterly 36(4): 439-466.

Houghton, D. P. (2007). Reinvigorating the Study of Foreign Policy Decision Making: Toward a Constructivist Approach. Foreign Policy Analysis 3(1): 24-45.

Howell, William G., and Jon C. Pevehouse. (2007) While Dangers Gather: Congressional Checks on Presidential War Powers. Princeton, NJ: Princeton University Press.

Høyland, Bjørn. (2010) Procedural and Party Effects in European Parliament Roll-Call Votes. European Union Politics 11(4): 597-613.

Hudson, V.M. (2005) Foreign Policy Analysis: Actor-Specific Theory and the Ground of International Relations. Foreign Policy Analysis 1(1): 1-30.

Hunter, James Davison. (1991) Culture Wars: The Struggle to Define America: Making Sense of the Battles over the Family. Art, Education, Law, and Politics.

Hurd, I. (2007). Breaking and Making Norms: American Revisionism and Crises of Legitimacy. International Politics 44(2): 194-213.

Hymans, Jacques EC. (2006) The Psychology of Nuclear Proliferation: Identity, Emotions and Foreign Policy. Cambridge: Cambridge University Press.

Jakobsen, J., Jakobsen, T., \& Ekevold, E. (2016) Democratic Peace and the Norms of the Public: A Multileval Analysis of the Relationship Between Regime Type and Citizens' Bellicosity, 1981-2008. Review Of International Studies 33(1): 1-24. 
Jenkins, Jeffery A., Michael H. Crespin, and Jamie L. Carson. (2005) Parties as Procedural Coalitions in Congress: An Examination of Differing Career Tracks. Legislative Studies Quarterly 30(3): 365-389.

Jervis, R. R. (2013) Do Leaders Matter and How Would We Know? Security Studies 22(2): 153179.

Jervis, R.R. (1976) Perception and Misperception in International Politics. Princeton, NJ: Princeton University Press.

Johnston, A. I. (1995) Thinking about Strategic Culture. International Security 19(4): 32-64.

Johnston, Alastair Iain. (2001) Treating International Institutions as Social Environments. International Studies Quarterly 45(4): 487-515.

Kaarbo, Juliet. (1996) Influencing Peace: Junior Partners in Israeli Coalition Cabinets. Cooperation and Conflict 31(3): 243-284.

Kaarbo, Juliet. (1997) Prime Minister Leadership Styles in Foreign Policy Decision Making: A Framework for Research. Political Psychology 18(3): 553-581.

Kaarbo, Juliet. (1998) Power and Influence in Foreign Policy Decision Making: The Role of Junior Coalition Partners in German and Israeli Foreign Policy. International Studies Quarterly 40(1): 501-530.

Kaarbo, Juliet, and Margaret G. Hermann. (1998) Leadership Styles of Prime Ministers: How Individual Differences Affect the Foreign Policymaking Process. Leadership Quarterly 9:243264.

Kaarbo, Juliet, and Ryan K. Beasley. (1998) A Political Perspective on Minority Influence and Strategic Group Composition. In Margaret A. Neale, Elizabeth A. Mannix and Deborah H. Gruenfeld. Eds. Research on Groups and Teams, Vol. 1. Stamford, CT: JAI Press.

Kaarbo, J., \& Beasley, R. K. (1999). A Practical Guide to the Comparative Case Study Method. Political Psychology 2(3).

Kaarbo, Juliet, and Ryan K. Beasley. (2004) Foreign Policy by Coalition: A Comparative Analysis of the Effects of Cabinet Characteristics on Event Behavior. Paper presented at the annual meeting of the American Political Science Association, Chicago, IL, September 2-5.

Kaarbo, Juliet. (2008) Coalition Cabinet Decision Making: Institutional and Psychological Factors. International Studies Review 10(1): 57-86.

Kaarbo, Juliet. (1998) Power Politics in Foreign Policy: The Influence of Bureaucratic Minorities. European Journal of International Relations 4(1): 67-97. 
Kaarbo, Juliet, and Ryan K. Beasley. (2008) Taking It to the Extreme: The Effect of Coalition Cabinets on Foreign Policy. Foreign Policy Analysis 4(2): 65-79.

Kaarbo, J., \& Cantir, C. (2013). Role Conflict in Recent Wars: Danish and Dutch Debates over Iraq and Afghanistan. Cooperation \& Conflict, 48(4): 465-483.

Kahler, M. (1998) Rationality in International Relations. International Organization 52(4): 919941.

Kamrava, Mehran. (2014) Mediation and Qatari Foreign Policy. The Middle East Journal 65(4): 539-556.

Katzenstein, P. ed. (1996) The Culture of National Security: Norms and Identity in World Politics. New York: Columbia University Press.

Keck, M. E., \& Sikkink, K. (1998). Transnational Advocacy Networks in the Movement Society. The Social Movement Society: Contentious Politics for a New Century. 217-238.

Keohane, R. (1984) After Hegemony: Cooperation and Discord in the World Political Economy. Princeton: Princeton University Press.

Keohane, R. O., \& Nye, J. S. (1997). Interdependence in World Politics. The Theoretical Evolution of International Political Economy: A Reader. Oxford: Oxford University Press.

King, G. and Lowe, W. (2003) An Automated Information Extraction Tool for International Conflict Data with Performance as Good as Human Coders: A Rare Events Evaluation Design. International Organization 57(3): 617-642.

Kirk, J. A. (2008). Indian-Americans and the US-India Nuclear Agreement: Consolidation of an Ethnic Lobby? Foreign Policy Analysis 4(3): 275-300.

Knecht, Thomas, and M. Stephen Weatherford. (2006) Public Opinion and Foreign Policy: The Stages of Presidential Decision Making. International Studies Quarterly 50(30): 705-727.

Köllner, Patrick, and Matthias Basedau, (2005) Factionalism in Political Parties: An Analytical Framework for Comparative Studies. German Overseas Institute Research Program on Legitimacy and Efficiency of Political Systems No.12, December. www.duei.de/workingpapers.

Korany, Bahgat, Ali E. Hillal Dessouki, and Aḥmad Yūsuf Aḥmad. The foreign policies of Arab states: the challenge of change. Westview Pr, 1991.

Krasner, S. D. (1978). Defending the National Interest: Raw Materials Investments and US Foreign Policy. Princeton, NJ: Princeton University Press.

Kratochwil, F. (1989). Rules. Norms and Decisions: On the Conditions of Practical and Legal Reasoning in International Relations and Domestic Affairs. Cambridge: Cambridge University 
Press.

Ku, C., and Paul Diehl. (1998). International Law as Operating and Normative Systems. In International Law: Classic and Contemporary Readings. Boulder, CO: Lynne Rienner.

Lantis, Jeffrey S. (2016) Arms and Influence: U.S. Technology Innovations and the Evolution of International Security Norms. Stanford, CA: Stanford University Press.

Lantis, Jeffrey S. ed. (2015) Strategic Culture and Security Policies in the Asia-Pacific. London: Routledge.

Lasswell, Harold D. (1951) The Immediate Future of Research Policy and Method in Political Science. American Political Science Review 45(1): 133-142.

Layman, Geoffrey C. and Thomas M. Carsey. (2000) Ideological Realignment in Contemporary American Politics: The Case of Party Activists. Paper presented at the Annual Meeting of the Midwest Political Science Association.

Lindaman, Kara, and Donald P. Haider-Markel. (2002) Issue Evolution, Political Parties, and the Culture Wars. Political Research Quarterly 55(1): 91-110.

Levy, J. S. (2003). Applications of Prospect Theory to Political Science. Synthese, 135(2): 215241.

Lijphart, Arend. (1971) Comparative Politics and the Comparative Method. American Political Science Review 65(3): 682-693.

Lobell, S. E., Ripsman, N. M., \& Taliaferro, J. W. (2009). Neoclassical Realism, the State, and Foreign Policy Cambridge: Cambridge University Press.

Maoz, Z., \& Russett, B. (1993). Normative and Structural Causes of Democratic Peace, 19461986. American Political Science Review 87(3): 624-638.

Maass, Anne, and Russell D. Clark. (1984) Hidden Impact of Minorities: Fifteen Years of Minority Influence Research. Psychological Bulletin 95:3.

Maass, Anne, Russell D. Clark, and Gerald Haberkorn. (1982) The Effects of Differential Ascribed Category Membership and Norms on Minority Influence. European Journal of Social Psychology 12(1): 89-104.

Mann, Thomas E., and Norman J. Ornstein. (2013) It's Even Worse than it Looks: How the American Constitutional System Collided with the New Politics of Extremism. New York: Basic Books.

Mann, Thomas E., and Norman J. Ornstein. (2006) The Broken Branch. New York: Oxford University Press. 
Maoz, Z., and B. Russett (1993). Normative and Structural Causes of Democratic Peace, 19461986. American Political Science Review 87(3): 624-638.

Marsh, K. (2014). Obama's Surge: A Bureaucratic Politics Analysis of the Decision to Order a Troo Surge in the Afghanistan War. Foreign Policy Analysis 10(3): 265-288.

Martin, L. L., \& Simmons, B. A. (1998). Theories and Empirical Studies of International Institutions. International Organization 52(4): 729-757.

Mayhew, David R. 1991. Divided We Govern: Party Control, Lawmaking and Investigations 1946-1990. New Haven, CT: Yale University Press.

McAllister, Ian. (1991) "Party Adaptation and Factionalism within the Australian Party System.” American Journal of Political Science 35(4): 206-227.

McCarty, Nolan, Keith T. Poole, and Howard Rosenthal (2006) Polarized America: The Dance of Ideology and Unequal Riches. Cambridge, MA: MIT Press.

McClelland, C.A. (1978) World Event/interaction Survey (WEIS), 1966-1978. Ann Arbor: Interuniversity Consortium for Political and Social Research.

McCourt, D. M. (2011). Role-playing and Identity Affirmation in International Politics: Britain's Reinvasion of the Falklands, 1982. Review Of International Studies 37(4): 1599.

McCourt, D. M. (2012) The Roles States Play: A Meadian Interactionist Approach. Journal of International Relations and Development 13(3): 370-392.

McDermott, R. (2011). New Directions for Experimental Work in International Relations. International Studies Quarterly 55(2): 503-520.

McGowan, P., and Shapiro, H.B. (1973) The Comparative Study of Foreign Policy: A Survey of Scientific Findings. Beverly Hills, CA: Sage.

Merritt, R. L. (1994). Measuring Events for International Political Analysis. International Interactions 20(1/2).

Milgram, Stanley. (1963) Behavioral Study of Obedience. The Journal of Abnormal and Social Psychology 67(4).

Miller, Gary, and Norman Schofield. (2008) The Transformation of the Republican and Democratic Party Coalitions in the US. Perspectives on Politics 6(3): 433-450.

Mora, Frank O., and Jeanne AK Hey. eds. (2004) Latin American and Caribbean Foreign Policy. Lanham, MD: Rowman \& Littlefield.

Moscovici, S, E. Lage, and M. Naffrechoux. (1969). Influence of a Consistent Minority on the Response of a Majority in a Color-Perception Task. Sociometry 32: 365-380. 
Moscovici, S., and C. Faucheux. (1972) Social Influence, Conformity Bias, and the Study of Active Minorities. in L. Berkowitz, ed. Advances in Experimental Social Psychology, vol.6, New York: Academic Press. 149-202.

Moscovici, S., and E. Lage. (1976) Studies in Social Influence III: Majority versus Minority Influence in a Group. European Journal of Social Psychology 6(2): 149-174.

Moscovici, Serge. (1976) Social Influence and Social Change. New York: Academic Press.

Moscovici, S. and B. Personnaz. (1980) Studies in Social Influence V: Minority Influence and Conversion Behavior in a Perceptual Task. Journal of Experimental Social Psychology 16: 270282.

Mugny, Gabriel, and Juan A. Pérez. (1991) The Social Psychology of Minority Influence. Cambridge: Cambridge University Press.

Mugny, Gabriel. (1975) Negotiations, Image of the Other, and the Process of Minority Influence. European Journal of Social Psychology 5(1): 209-229.

Nacos, Brigitte, Robert Y. Shapiro, and Pierangelo Isernia, eds. (2000) Decisionmaking in a Glass House: Mass Media, Public Opinion, and American and European Foreign Policy in the $21^{\text {st }}$ Century. New York: Rowman \& Littlefield Publishers.

Nathan, J., and J. Oliver (1978) Bureaucratic Politics: Academic Windfalls and Intellectual Pitfalls. JPMS: Journal of Political and Military Sociology 6(1): 81.

Neack, L., J. Hey, and P. Haney. Eds. (1995) Foreign Policy Analysis: Continuity and Change in Its Second Generation. Englewood Cliffs, NJ: Prentice Hall.

Nemeth, Charlan, and Joel Wachtler. (1973) Consistency and Modification of Judgment. Journal of Experimental Social Psychology 9:65-79.

Nemeth, Charlan, and Joel Wachtler. (1974) Creating the Perceptions of Consistency and Confidence: A Necessary Condition for Minority Influence. Sociometry 37(4): 529-540.

Nivola, Pietro S., and David W. Brady, eds. (2006) Red and Blue Nation? Vol. 1: Characteristics and Causes of America's Polarized Politics. Washington, DC: Brookings Institution Press.

Nzomo, M., and G.A. Nweke (1982). Harmonization of African Foreign Policies, 1955-1975: The Political Economy of African Diplomacy. Boston, MA: Boston University Press.

Oktay, S. and Beasley, R. (2016). Quantitative Approaches in Coalition Foreign Policy: Scope, Content, Process. European Political Science.

Onuf, N., and F.F. Klink (1989). Anarchy, Authority, Rule. International Studies Quarterly 33(2): 149-173. 
Ovah, Ş. (2013). Decoding Turkey's Lust for Regional Clout in the Middle East: A Role Theory Perspective. Journal of International and Area Studies 1(1).

Ozkececi-Taner, B. (2006) Reviewing the Literature on Sequential/Dynamic Foreign Policy Decision Making. International Studies Review 8(3): 545-554.

Palmer, G., D’Orazio, V., Kenwick, M., \& Lane, M. (2015). The MID4 dataset, 2002-2010: Procedures, coding rules and description. Conflict Management \& Peace Science 32(2).

Peake, Jeffrey S., Glen S. Krutz, and Tyler Hughes. (2012) President Obama, the Senate, and the Polarized Politics of Treaty Making. Social Science Quarterly 93(5): 1295-1315.

Peake, Jeffrey S. (2002) Coalition Building and Overcoming Legislative Gridlock in Foreign Policy, 1947-98. Presidential Studies Quarterly 41(4): 67-83.

Perez, Juan A., and Gabriel Mugny. (1987) Paradoxical Effects of Categorization in Minority Influence: When Being an Outgroup Is an Advantage. European Journal of Social Psychology 17(2): 157-169.

Peterson, Randall. (1997) A Directive Leadership Style in Group Decision Making Can Be Both Virtue and Vice: Evidence From Elite and Experimental Groups. Journal of Personality and Social Psychology 72(3): 1107-1121.

Qingmin, Zhang. (2016) Bureaucratic Politics and Chinese Foreign Policy. Chinese Journal of International Politics 9(4): 435-458.

Rae, Nicol C. (1989) The Decline and Fall of the Liberal Republicans: from 1952 to the Present. New York: Oxford University Press.

Rathbun, Brian. (2013) Steeped in International Affairs?: The Foreign Policy Views of the Tea Party. Foreign Policy Analysis 9(1): 21-37.

Reiter, Howard L. (1998) The Bases of Progressivism within the Major Parties. Social Science History 22(1): 83-116.

Reiter, Howard L. (1981) Intra-party Cleavages in the United States Today. Political Research Quarterly 34(2): 287-300.

Reiter, Howard L. (1980) Party Factionalism National Conventions in the New Era. American Politics Quarterly 8(3): 303-318.

Rosati, Jerel A. (2000) The Power of Human Cognition in the Study of World Politics. International Studies Review 2(3):45-75. 
Rose, G. (1998). Neoclassical Realism and Theories of Foreign Policy. World Politics 50(1): 144-172.

Rosenau, J. N. (1966). Turbulence in World Politics. History 7(2): 279-92.

Rousseau, D. L., Gelpi, C., Reiter, D., \& Huth, P. K. (1996) Assessing the Dyadic Nature of the Democratic Peace, 1918-88. American Political Science Review 90(3): 512-533.

Rublee, Maria Rost. (2008) “Taking Stock of the Nuclear Nonproliferation Regime: Using Social Psychology to Understand Regime Effectiveness.” International Studies Review 10(30: 420-450.

Sampson, M. (1987) Cultural Influences on Foreign Policy. In C.F. Hermann, C.W. Kegley, and J.N. Rosenau. Eds. New Directions in the Study of Foreign Policy. Boston: Allen and Unwin. 384-408.

Sartori, Giovanni. (1976) Parties and Party Systems: A Framework for Analysis, Vol. 1. Cambridge: Cambridge University Press.

Shaw, T. M., \& Okolo, J. E. (1994). The Political Economy of Foreign Policy in ECOWAS. Berlin: Springer Verlag.

Schrodt, Phil. (1995) Event Data in Foreign Policy Analysis. In Neack, Hey, and Haney.eds. Foreign Policy Analysis: Continuity and Change in Its Second Generation. Englewood Cliffs, NJ: Prentice Hall.

Shain, B. A. (1994). The Myth of American Individualism: The Protestant Origins of American Political Thought. Princeton, NJ: Princeton University Press.

Shapiro, R., \& Jacobs, L. (2000). Who Leads and Who Follows?. Decisionmaking in Glass House: Mass Media, Public Opinion, and American and European Foreign Policy in the $21^{\text {st }}$ Century.

Sherif, Muzafer. (1935) A Study of Some Social Factors in Perception. Archives of Psychology (Columbia University).

Sieberer, W. (2006) "Party Unity in Parliamentary Democracies: A Comparative Analysis.” Journal of Legislative Studies 12(1): 150-178.

Sinclair, Barbara. (1997) Unorthodox Lawmaking: New Legislative Processes in the U.S. Congress. Washington, DC: CQ Press.

Sindler, Allan P. (1955) Bifactional Rivalry as an Alternative to Two-Party Competition in Louisiana. American Political Science Review 49(3): 641-662.

Singer, J. D. (1961). The Level-of-Analysis Problem in International Relations. World Politics $1(1)$. 
Smillie, I., \& Minear, L. (2004). The Charity of Nations: Humanitarian Action in a Calculating World. Bloomfield, CT: Kumarian Press.

Smith, S. (1987) CFP: A Theoretical Critique. International Studies Notes 13(2): 47-48.

Snyder, R.C., H.W. Bruck, H.W., and B. Sapin. (1954) Decision-Making as an Approach to the Study of International Politics. Princeton, NJ: Princeton University Press.

Sprout, H., and M. Sprout (1956) Man-Milieu Relationship Hypotheses in the Context of International Politics. Princeton, NJ: Princeton University Press.

Sprout, H., and Sprout, M. (1957) Environment Factors in the Study of International Politics. Journal of Conflict Resolution 1(3): 309-328.

Stecker, Christian. (2013) How Effects on Party Unity Vary Across Votes. Party Politics 21(5): 791-802.

Sun, Yun. (2014) Africa in China's Foreign Policy. Washington, DC: Brookings Institution. https://www.brookings.edu/wp-content/uploads/2016/06/Africa-in-China-web_CMG7.pdf.

Tanford, Sarah, and Steven Penrod. (1984) Social Influence Model: A Formal Integration of Research on Majority and Minority Influence Processes. Psychology Bulletin 95(2): 189-225.

Telhami, Shibley (2002) Kenneth Waltz, Neorealism, and Foreign Policy. Security Studies 11(2): 158-a70.

T’Hart, Paul, Eric K. Stern, and Bengt Sundelius. Eds. (1997). Beyond Groupthink: Political Group Dynamics and Foreign Policy-Making. Ann Arbor, MI: University of Michigan Press.

Thies, C. (2010) Role Theory and Foreign Policy. In: R.A. Denemark. Ed. The International Studies Encyclopedia. Oxford: Blackwell; Blackwell Reference Online.

Thies, C. (2012) International Socialization Processes vs. Israeli National Role Conceptions: Can Role Theory Integrate IR Theory and Foreign Policy Analysis? Foreign Policy Analysis 8(1): 25-46.

Thies, C. (2013) The United States, Israel, and the Search for International Order: Socializing States. London: Routledge.

Tickner, J. (1997) You Just Don’t Understand: Troubled Engagements Between Feminists and IR Theorists. International Studies Quarterly 41(4): 611-632.

Vertzberger, Y.Y.I. (1990). The World in Their Minds: Information Processing, Cognition, and Perception in Foreign Policy Decision Making. Stanford, CA: Stanford University Press.

Vieira, Marco A. (2013) Brazilian Foreign Policy in the Context of Global Climate Norms. 
Foreign Policy Analysis 9(2).

Wachtler, J.B. (1977). The Effect of Conformity versus Minority Influence Settings on the Individual's Ability to Locate Non-Obvious Solutions in a Hidden Figures Test. Dissertation Abstracts International.

Walker, S.G. (1987) Role Theory and Foreign Policy Analysis. Durham, NC: Duke University Press.

Wallerstein, I. (1974). The Rise and Future Demise of the World Capitalist System: Concepts for Comparative Analysis. Comparative Studies in Society and History 16(4): 387-415.

Weeks, Jessica L. (2012) Strongmen and Straw Men: Authoritarian Regimes and the Initiation of International Conflict. American Political Science Review 106(2): 326-347

Wehner, Leslie E. (2015) Role Expectations As Foreign Policy: South American Secondary Powers' Expectations of Brazil As A Regional Power. Foreign Policy Analysis 11(4): 435-455.

Wehner, Leslie E. and Cameron G. Thies. (2014) Role Theory, Narratives, and Interpretation: The Domestic Contestation of Roles. International Studies Review 16(3): 411-436.

Weinstein, J. M. (2006). Inside Rebellion: The Politics of Insurgent Violence. Cambridge: Cambridge University Press.

Weissman, Stephen R. (1995) A Culture of Deference: Congress's Failure of Leadership in Foreign Policy. New York: Basic Books/Harper Collins.

Wendt, A. (1999) Social Theory of International Politics. Cambridge: Cambridge University Press.

Wesley, Michael, and Sergei DeSilva-Ranasinghe. (2011). The Rise of India and its Implications for Australia Policy 27(2).

White, Brian (1999) The European Challenge to Foreign Policy Analysis. European Journal of International Relations 5: 37-66.

Williamson, Vanessa, Theda Skocpol, and John Coggin. (2011) The Tea Party and the Remaking of Republican Conservatism. Perspectives on Politics 9(1): 25-43.

Wish, N.B. (1980) Foreign Policy Makers and National Role Conceptions. International Studies Quarterly 24(4): 532-54.

Wivel, A. (2005) The Security Challenge of Small EU Member States: Interests, Identity and the Development of the EU as a Security Actor. Journal of Common Market Studies 43(3): 393-412.

Wohlforth, W. C. (2008). Realism and Foreign Policy. Foreign Policy: Theories, Actors, Cases. 
Wood, Wendy, et al. (1994) Minority Influence: A Meta-analytic Review of Social Influence Processes. Psychological Bulletin 115(3).

Yin, Robert K. 2003. Case Study Research Design and Methods. Thousand Oaks, CA: Sage.

Young, Michael D. and Mark Schafer. (1998) Is There a Method in Our Madness? Ways of Assessing Cognition in International Relations. Mershon International Studies Review 4(2): 6396.

Zakaria, Fareed. (2003) The Future of Freedom. New York: W.W. Norton \& Company, Inc.

Zariski, Raphael. (1960) Party Factions and Comparative Politics: Some Preliminary Observations. Midwest Journal of Political Science 4(1): 27-51.

Zambernardi, L. (2016). Politics is too Important to be Left to Political Scientists: A Critique of the Theory-Policy Nexus in International Relations. European Journal Of International Relations 22(1): 3-23. 